\title{
Influencers - Contemporary Authorities of the Young Generation?
}

\author{
By Katarzyna Garwol ${ }^{1}$
}

\begin{abstract}
Over the past decade computers and smartphones connected to the internet have become widespread, that is why they are now an inseparable element of all ages people's life, especially young people who do not remember the times when such devices were not used. It is commonly used saying that present-day youth "were born with a smartphone in their hands." In the Network young people lead their social life, search for information on various topics and also watch social networking sites, where so-called influencers i.e. network celebrities run their thematic profiles. Content posted by influencers is not always valuable and it happens that they cross the law line and push the boundaries of good taste. An example can be currently popular "patostreams" i.e. live broadcasts, during which behaviors considered as social deviations are presented such as domestic violence, alcohol libations or vulgar discussions. The goal of influencers is to arouse interest in their profile in social media which translates into the number of followers and in turn is supposed to contribute followers' decisions (e.g. shopping) and opinions on the topics presented. Young people, who have no experience and critical overview and their maturity is just developing, often spend many hours a week in the virtual space watching influencer messages. The article will attempt to answer the questions on how young people approach the content presented by influencers, whether influencers shape followers opinions and decisions in various aspects of life and whether they are authorities to be imitated and trusted.
\end{abstract}

Keywords: influencer, celebrity, influence, internet, youth

\section{Introduction}

Contemporary youngsters grew up in a completely different socio-technical conditions than their parents did. In the $21^{\text {st }}$ century, the world was flooded by available digital gadgets and the broadband Internet could be accessed in all so-called First World Countries. A real technological revolution became a fact when smartphones with the access to the Internet were widespread. The first smartphone was presented in 1992 by the American company IBM and was called Simon. In 2013 smartphones overtook the traditional mobile phones (Polskatimes 2019). It was related to more and more advanced operational systems created for mobile phones that allowed for easier and more intuitive usage.

This huge progress in the matter of IT technology caused that a great part of life of especially young people happened in the virtual reality where social websites played a great role and gathered Internet users. In 2004 Facebook appeared and in 2005 YouTube (Długosz 2018) was created and in 2010 Instagram emerged that was bought by Facebook in 2012. In the following years more social networking sites appeared being a platform for exchanging photos, information and films between users. 
Opportunities of reaching the recipients given by the social networking sites were soon notices by people who decided by this means to promote themselves or their business. It is how influencers appeared, who by their entries in social media not only do influence people's decisions but also have relationship with them and the latter identified themselves with them. These are usually people who write a blog, vlog, have an account on Instagram, YouTube or some other social networking site and who are able to influence a group of a least hundreds of people (Whitepress 2016).

A person with less than a few hundreds of followers cannot be named an influencer. Coverage in the Internet decides whether somebody is an influencer or not. The more groups the influencer gathers around him/her the more valuable he/she becomes for the companies that decide to cooperate. The biggest group of followers constitute young people who have been using smartphones and the Internet since they were born. Students of the University of Rzeszów constitute such a group and they are the respondents of this study. On the basis of their answers to an on-line questionnaire it was attempted to diagnosed whether influencers have an impact on contemporary young people and if yes, in which areas and to what extend and if that influence is so important that they could be named authorities of young generation.

\section{Authority - Difficulties with Defining and Typology}

Issues related to the authority have been repeatedly raised. Researchers tried to define what an authority is, what criteria need to be fulfilled for a person to become an authority for others and how authorities have changed over the years. According to A. M de Tchorzewski term authirity could be understood in at least two ways. The first term is understood as features of a person or an institution to which it is assigned on the basis of common and social approval and it is implied from above without doubts (official). The second term is a result of some research in the area of interpersonal relation, when individuals or groups of their own accord search for a person or an institution that they trust, doing this due to their inner perfection and the source of norms which are important for them and which they use in their lives (Tchorzewski 2017).

The term authority stems from the Latin words auctoritas, auctoritatis meaning importance, influence, role model, example, reliability (Wasylewicz 2016). Initially, this term was associated with the Senate of the ancient Rome (auctoritas senatus), which consisted of mighty family leaders who made legislative decisions. Here comes the Cicero's maxim: "Power lies with the people, authority rests in the Senate" (Jacko 2007). Contemporary, definitely most definitions of authority, especially in humanities, has neither closed nor absolute character, which is related to a number of linguistic limits and the ground and environment they appear and are used (Piórkowski 2016).

Encyclopedic definition defines authority as "a category or psychological psychosocial phenomenon described in science on human in order to mark an importance influence made by a person or an institution on the development of mentality or relations between people accepting submissive statements and standards feeling respect at the same time and considering their importance, sovereignty or competence; it is usually distinguished between authority of law, competence, conscience and religious" (Encyklopedia PWN 2018). Thus, it is a relation happening between at least two people, or between a person 
and an institution, one of whom arises respect and appreciation for another person.

T. Gordon draws attention to the duality of this term, relating it to two meanings: knowledge, experience, competence or power, the right to control, the right to indicate, the power to penalize in case of abusing rules of right behavior (e.g. the boss remain authoritative over employees, the court over the citizens) (Drzeżdżon 2011). On the other hand, E. Durkheim in the book 'Education morale' defines authority as a feature "that a real person possesses or ideal in relation to specified individuals thanks to which it is considered as gifted with some higher superpower than it assigns itself" (Drzeżdżon 2011). M. Lobocki claims that authority is not any value itself but it is dependent on other people who decide to submit to a particular person. Authority is not given once and for all. It is really difficult to become an authority and it could be strengthened, weakened or it might completely disappear (Drzeżdżon 2011).

Attempts to define what an authority is led to a creating a number of ideas related to the role of an authority in the social life. I.R. Simon is an author of one of the most relevant ideas. He constructed it on the basis of an idea of common good. He stressed that common good exists objectively as an important feature of each society and people naturally desire implementing the common good. Wise people desire good in a conscious way whereas people deprived of good will and reason must be prompted to common good. In this process he assigned a great role to people being authorities. Such people are able to penetrate a range of aims contributing to common good and simultaneously thanks to the ability to specify the aims they are perceived by others as authorities (Tasak 2015).

Authorities can be authentic (real) and apparent (unreal, not authentic). Authentic authority has features that let him influence other people, but apparent authority has no such features. A person regarded as a specialist in a given area is an authentic authority only when they are such specialists. Otherwise, they can be apparent authorities. Apparent authorities give the impression of authentic authorities but they are not ones. They build up their position by misinforming, manipulating or threatening. When people realize that they are being under control of the authority, we deal with conscious authority, otherwise it is unconscious authority. Unconscious authority influences people without their consent so they are not authorities of choice (Jacko 2007).

As it can be seen there are many definitions and typologies of an authority and with the progress in research of the area their contemporary versions are created. Typologies sometimes are based on selected criteria and another time on several criteria at one time. In order to name someone authority they need to have an influence on other people, command their respect and provoke to follow model behavior and life values. It seems that the name influencer defines a given person as someone who has an influence on others and predispose them to an authority for the public. This study aims at diagnosing if it is a fact.

\section{Methodology}

This article aims at answering a question what impact influencers have on young people and how they are perceived by Internet observers and whether they could be named as contemporary authorities for young generation. The research was conducted in 
months March - April 2020 by the means of Internet questionnaire, done on the platform ankiety.interaktywnie.com.

522 students of the University of Rzeszów took part in the research, 52 studying humanities, 47 studying engineering, 48 studying medical subjects, 232 studying social science, 136 studying science and 36 studying art. The majority of students studied fulltime (497 - full-time students, 28 - part-time students), bachelor's students (445), master's students (81), not employed (404), employed (121), aged 20-25 (483 - 20-25; 14 -below 19; 12 - aged 26-30; 8 - aged 31-40; 5 - aged 41 - 50). The majority of respondents lived in the village (298), 97 respondents came from the cities with over 100 thousand inhabitants, 79 from the cities with less than 50 thousand inhabitants and 48 from the cities with 50 thousand -100 thousand inhabitants. More women (313) than men (209) participated in the research.

The questions were generally closed and either single or multiple-choice. Some of the questions allowed the respondents to give their own answers, one question was open and let for free response.

\section{Results}

Influencers' profiles on the social networking sites were popular among the respondents. Almost two thirds $(65,5 \%)$ admitted to observing them and more than a half spent nearly an hour doing it (59\%), one third 1-2 hours a day (29,4\%), $7 \%$ spend 34 hours a day and 3.9\% more than 4 hours. Instagram was the application that was most frequently used to observe influencers' profiles (90,5\%), almost a half of respondents used Facebook for this purpose (48,4\%), Snapchat (13,5\%), Twitter $(6,6 \%)$ and YouTube $(8,6 \%)$ were less frequently used. The subject matter of the social networking sites that was of the greatest popularity was light and did not demand too much of intellectual involvement. The most popular profiles were devoted to a lifestyle $(61,2 \%)$, fashion and beauty (59,5\%), a bit less popular were about travelling $(47,7 \%)$, entertainment $(44,2 \%)$, sport $(42,8 \%)$ very few observed influencers writing about religion, art, cooking or culture (all together $4 \%$ ).

\section{What is the subject matter of the influencers' profiles that you observe?}

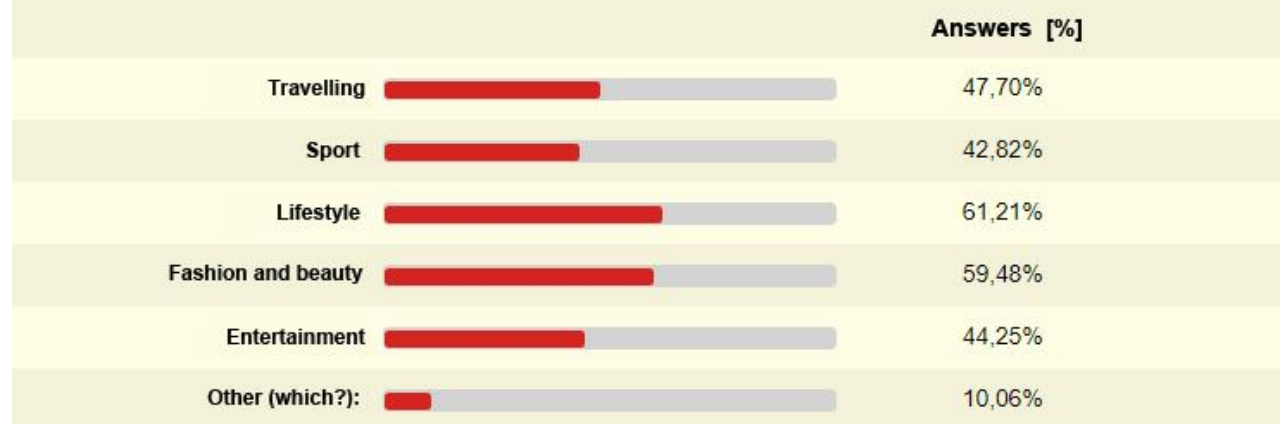

Figure 1. The subject matter of the profiles observed by the respondents $(N=348)$

Source: author's own analysis. 
The respondents believed that influencers had a big influence on their followers in various aspects of life, however, the impact varied depending on the areas. They significantly influenced e.g. shopping decision of their observers. Ranking from 1 (the smallest influence) to 5 (the biggest influence), answer 4 was the most frequently chosen $(31,9 \%)$. Influencers have an impact on the way their followers perceive the world (answer number $4-29,9 \%$ ) as well as on the way they perceive themselves (answer number $4-28,5 \%$ ), and on the self-presentation (answer number $4-29,7 \%$ ), on the lifestyle of the respondents (answer number $4-32,2 \%$ ), the way they dress (answer number $4-30.2 \%$, answer number $5-30,8 \%$ ). They have a bit less influence on the values and priorities of the respondents (answer number $3-29,3 \%$ ) and their interests (answer number $3-26,2 \%$ ).

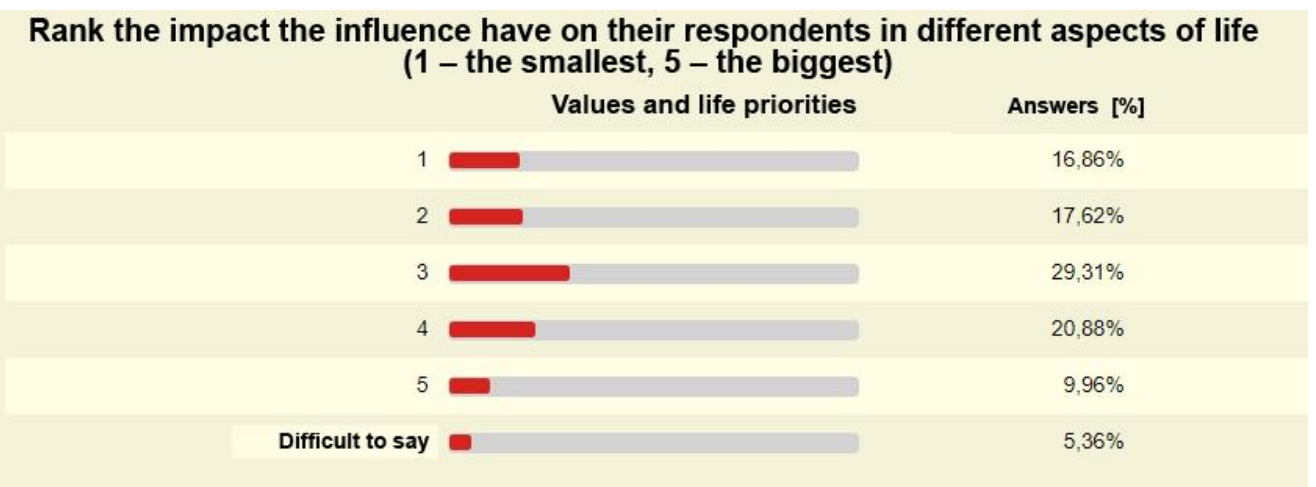

Figure 2. The influencers' impact on the observers' values and priorities $(N=522)$

Source: author's own analysis.

The respondents found it difficult to specify whether such the influence of the people running their profiles in the social media is a positive or a negative phenomenon. $65,5 \%$ of the respondents had no opinion on the issue, 19,9\% stated that it was a negative phenomenon and $14,5 \%$ that it was positive.

\section{The influencers' impact on the observers you regard as a phenomenon that is:}

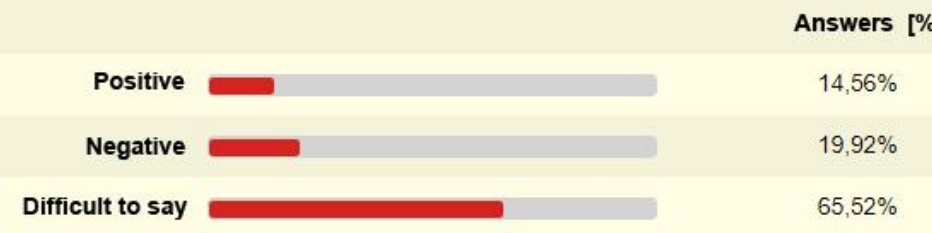

Figure 3. The assessment of the influencers' impact on the observers by the respondents $(N=522)$

Source: author's own analysis. 
Nearly a half of the respondents (42,3\%) admitted to having made a shopping decision on the basis of what the influencers presented in their social media and $10 \%$ of the respondents changed their decision on a given subject being under the influence on the entry. Things that changed their opinions were e.g. product review, which the influencers presented or a constructive comment on a given product or issue.

\section{Has the influencer's entry made you change your opinion on a given issue?}

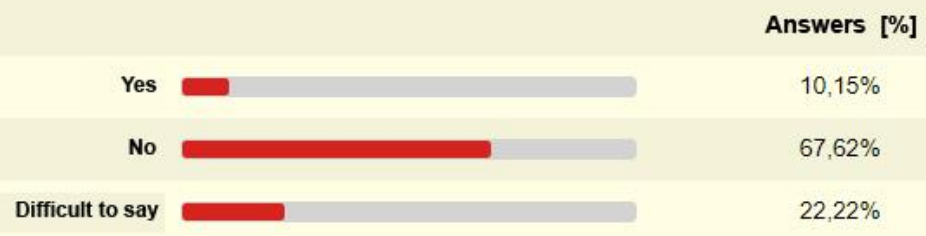

Figure 4. The influencers' impact on changing observers' opinions (N=522)

Source: author's own analysis.

Due to the fact that this research was conducted in the initial phase of the restrictions introduced because of the spreading coronavirus in Poland, the respondents regarded travel profiles as the most prone to lose popularity. 66,3\% of the respondents answered they would lose popularity and 9,6\% that they would gain popularity, 14,9\% stated that they would neither lose nor gain popularity and $9,2 \%$ was of no opinion. Pandemic coronavirus was expected to increase the popularity of profiles devoted to health $(83.9 \%$ increased popularity), entertainment $(52,8 \%)$, lifestyle $(46,7 \%)$ and sport (a bit less $39,6 \%)$.

In the view of the respondents pandemic will have an impact on the way the Internet users perceive the influencers. In particular, profiles related to healthy lifestyle $(43,1 \%)$ will gain popularity and profiles with so-called 'light' subject matter will be observed more frequently as they give the observers the opportunity to forget the worries of everyday life $(41,9 \%)$. Almost one quarter of the respondents $(22,2 \%)$ stated that people would re-evaluate their approach to life and notice the fact that a lot of contents presented by the influencers has no value. Moreover, during pandemic lifestyle profiles will lose popularity but they will regain it after the pandemic ends $(18,7 \%)$ and the Internet users will come to a conclusion that it is pointless to read uninteresting contents $(15,9 \%)$. It will lead to a lost in popularity of unimportant contents as the epidemics has changed the attitude to life and time that is given to people. 


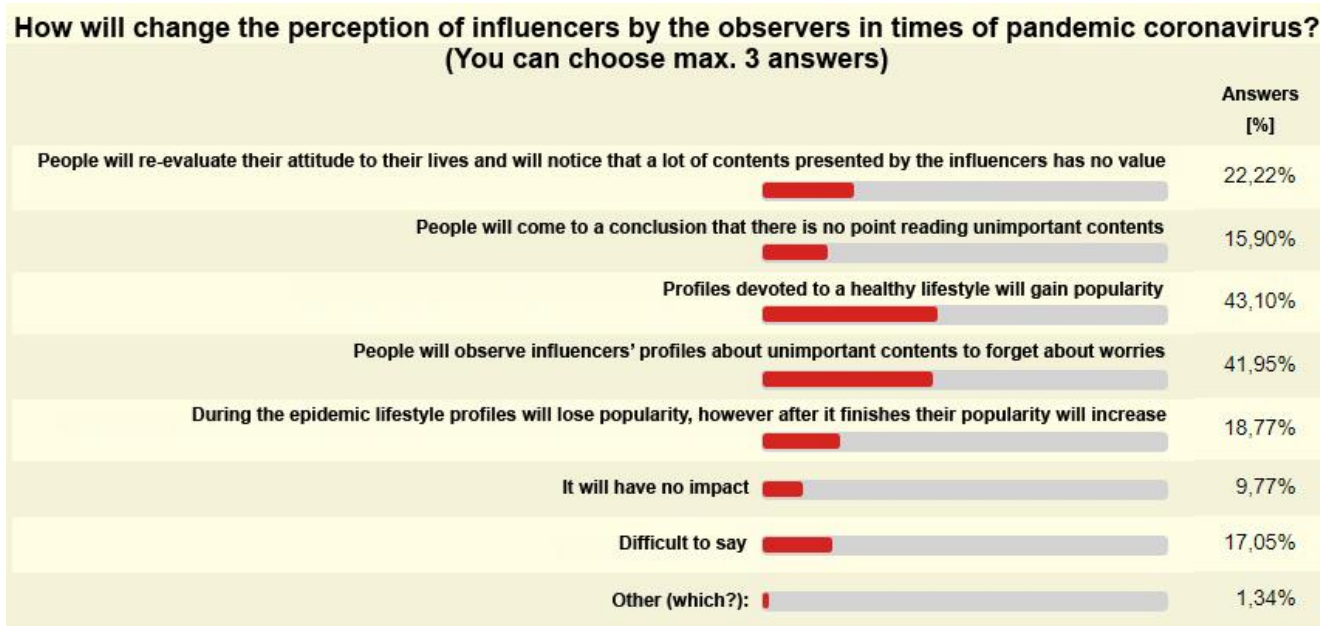

Figure 5. The influence of the pandemic coronavirus on the perception of influencers by the Internet users Source: author's own analysis.

Despite the fact that influencers have appeared in the virtual reality over the last decade, undoubtedly, they have an established position in it. Almost one third of the respondents considered their appearance as a positive phenomenon $(31 \%)$, as a negative $(20,7 \%)$ and almost half of the participants were of no opinion (48,3\%). The respondents did not plan to become influencers and the majority of them were against it $(70,7 \%)$, or they had no opinion $(15,7 \%) .8$ respondents $(1,5 \%)$ admitted to being influencers and that fight for observers.

\section{Summary}

An analysis of the empirical data allows to state that influencers have a big impact on their followers in issues related to both making decisions (e.g. shopping) as well as worldview issues. Taking into account the definitions of authority mentioned about in the article, it could be stated that they often become an authority for their observers in the social media. A lot of them are authentic (real) authorities, being specialists in their area, nonetheless, there are also apparent authorities whose competence and qualifications are unknown or they do not possess them. Influencers are usually conscious authorities as the respondents could point the areas which they influence, and they were aware of this impact. Additionally, the impact of the influencers on the observers happened under the consent of the latter as all Internet users decide on their own whose profile they are going to observe in the social media.

Followers are usually young people whose views are being formulated. That is the reason why they are under the influence of others and have no critical approach to a lot of issues. So it might happen that people who do not deserve to be named authority as they have nothing valuable to offer become one. Due to that fact both quality and credibility of the contents presented in the Internet are so important. Pandemic coronavirus made a lot of young people wonder what contents they are provided with in the Internet and 
they verified the point of spending time on trivial contents. It seems to be a positive phenomenon as all show-offs who promote light-hearted lifestyle and luxury lose their popularity.

\section{References}

Encyklopedia PWN. (2018). Authority, http://encyklopedia.pwn.pl/szukaj/autorytet. Accessed 05/03/2020.

Długosz, D. (2018). Pierwszy film opublikowany w serwisie YouTube ma już 13 lat. Pamiętacie to wideo? https://www.komputerswiat.pl/aktualnosci/internet/pierwszy-film-opublikowany-w-serwisieyoutube-ma-juz-13-lat-pamietacie-to-wideo/nw2q96w. Accessed 24/04/2018.

Drzeżdżon, W. (2011). Pedagogiczne uwarunkowania autorytetu nauczyciela-wychowawcy. In: Jezylk - S zkoła - Religia 2011/6 (pp. 113-124). Gdańsk: Uniwersytet Gdański.

Jacko, J. F. (2007). Typy i funkcje autorytetu w „,czasach nieufności”. In G. P. Maj (Eds.), Komunikacja marketingowa w czasach nieufności. Radom: Wyższa Szkoła Handlowa w Radomiu. p. 20.

Kowalska, J. (2017). Historia potęgi, czyli jak Facebook podbił świat, https://marketingibiznes.pl/socialmedia/historia-potegi-czyli-jak-facebook-podbil-swiat/. Accessed 16/02/2017.

Piórkowski, P. D. (2016). Autorytety. Idole, pozory, eksperci i celebryci (p. 9). Stare Miasto: Witanet.

Polskatimes. (2019). Kto wynalazł telefon: dotykowy, komórkowy, stacjonarny? Niewielu zna tę historię. Sprawdźcie, kto i kiedy wynalazł telefon, https://polskatimes.pl/kto-wynalazl-telefon-dotykowykomorkowy-stacjonarny-niewielu-zna-te-historie-sprawdzcie-kto-i-kiedy-wynalazl-telefon/ar/c1514017615. Accessed 02/04/2019.

Socialmedia. (2018). Historia powstania Instagrama, https://socialmedia.biz.pl/historia-powstania-instagrama/. Accessed 12/08/2018.

Tasak, A. (2015). Autorytet władzy - władza autorytetu. Autorytety w polskiej przestrzeni publicznej. In: Studia Politologica XV (p. 193-204). Kraków: Uniwersytet Pedagogiczny.

Tchorzewski, A. M. (2017). Autorytet i jego struktura aksjologiczna. In Studia Paedagogica Ignatiana, Vol 20/2017/5 (pp. 187-212). Kraków: Akademia Ignatianum w Krakowie.

Wasylewicz, M. (2016). Autorytety Medialne - starcie czy wsparcie (?) Autorytety realnych mediów współczesnej młodzieży. In: Lubelski Rocznnik Pedagogiczny T. XXXV (p. 99-109). Lublin: Uniwersytet Marii Cure Skłodowskiej, p. 100. doi: 10.17951/lrp.2016.35.1.99

Whitepress. (2016). Kim jest influecner, po zasiegach ich poznacie. https://www.whitepress.pl/bazawiedzy/275/kim-jest-influencer-po-zasiegach-i-charyzmie-ich-poznacie. Accessed 08/12/2016. 